\title{
MENSAJE DE LA DIRECTORA DE LA ESCUELA GRADUADA DE TRABAJO SOCIAL
}

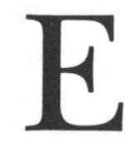

ste segundo volumen de la Revista Análisis es una muestra de la diversidad de intereses que nutre la práctica profesional de trabajadores y trabajadoras sociales. Algunos de los temas tratados incluyen modelos de bienestar y desarrollo integral, tratamiento penitenciario, mujeres con cáncer, abuso a personas de mayor edad, tranvestismo, racismo y política social, globalización, inserción y reinserción social. Esta diversidad temática demuestra a su vez los énfasis que conviven, no siempre armónicamente, al interior de la profesión.

Desde sus orígenes como práctica profesional y disciplina de estudio, el trabajo social adopta dos niveles diferentes de intervención. Uno de estos acercamientos enfatiza en el servicio directo a las personas que de una u otra forma están excluidas del bienestar social y humano al que todos y todas tenemos derecho. La finalidad a este nivel es apoyar los esfuerzos de la persona, o todo su grupo familiar, para resolver una situación limitante o a alcanzar su pleno desarrollo. El otro acercamiento pone énfasis en lograr cambios en los sistemas y estructuras socioeconómicas que permiten o crean las diversas formas de exclusión social y económica.

Ahora bien, ¿̇cuál es el elemento que unifica esta práctica profesional y disciplina de estudio de intereses, temáticas y perspectivas tan variadas? A mi juicio, esta función la ejercen los principios éticos que originan el trabajo social. La base valorativa de la profesión postula un compromiso con la búsqueda del bienestar 
humano, la promoción de la justicia social y económica y el respeto a la dignidad de las personas. Se señala así el deber de aquellos y aquellas que abrazan la profesión de defender el derecho de toda persona a ser tratada en forma no discriminatoria y el derecho de los diversos sectores y grupos sociales a tener igual acceso a las oportunidades existentes para satisfacer las necesidades humanas básicas. Estos valores son el hilo conductor de toda práctica profesional en trabajo social. De ahí que a pesar de que los trabajadores y trabajadoras sociales pongamos nuestra atención en poblaciones específicas o en políticas sociales y económicas particulares, la finalidad última, la función o el interés, tiene una veta común: contribuir a mejorar las condiciones de vida en la sociedad.

La base valorativa de la profesión también nos señala el camino a seguir durante conflictos sociales profundos. Por ejemplo, en estos momentos Puerto Rico atraviesa una coyuntura histórica crítica. El pueblo puertorriqueño y en particular los habitantes de uno de sus municipios -Vieques- vive momentos determinantes. La Marina de Guerra de Estados Unidos les utiliza como campo de prácticas bélicas para poner a prueba la capacidad de sus bombas, incluyendo nucleares, en detrimento de la paz, la salud, el ambiente, y hasta la vida misma de los y las viequenses. Tras sesenta años de bombardeos, hay una toma de conciencia colectiva sobre la violación de derechos a la que se ha estado sujeto. Este cambio en la conciencia crítica del pueblo genera una confrontación por detener estas prácticas a todas luces discriminatorias y abusivas.

Una reflexión desde la ética profesional muy bien puede ayudar a los y las trabajadoras sociales a definir cual es la posición correcta ante el presente conflicto. Si abrazamos el compromiso básico con la dignidad humana, el bienestar social y la justicia social y económica -valores que como señaláramos distinguen la profesión de trabajo social desde sus orígenes- el camino es inequívoco. Estos nos ubican al lado de los que defienden la dignidad de los viequenses manifestada en su lucha por defender y proteger su salud, su vida, su ambiente y su derecho a un desarrollo social y económico pleno.

Nuevamente son los valores de la profesión, ese gran elemento unificador, los que nos permitirán, dentro de nuestra diversidad ideológica o política, aglutinar con efectividad nuestros esfuerzos. Es esa ética de la profesión, a la que debemos acudir cuando estamos de frente a dilemas sociales. Ella nos permitirá 
rebasar diferencias marginales y unirnos como grupo en búsqueda del bien común. Compromiso que asumimos al ingresar en esta profesión.

Existe otro grupo de valores contenidos en los Códigos de Etica de los diversos países donde se practica la profesión. Estos van dirigidos a regular la relación entre colegas y entre los profesionales del trabajo social y la profesión misma. Estos valores enfatizan la colaboración entre practicantes de la profesión, el intercambio de información y conocimiento, la amplia difusión de ideas y el compromiso con generar nuevo conocimiento. Estos precisamente son los valores que subyacen en la creación de una revista como la que tenemos ante nosotros.

La Revista Análisis intenta ser instrumento y puente de comunicación a través del cual practicantes, educadores/as e investigadores/as del trabajo social puedan compartir las interpretaciones y ponderaciones que hacen de sus experiencias profesionales y de los procesos sociales dentro de los que se enmarca su práctica. De esta forma se busca contribuir al fortalecimiento y al desarrollo de la profesión de trabajo social.

En aras de ampliar sus posibilidades como vehículo de intercambio de reflexiones, la revista incorpora partir de este segundo volumen una sección de artículos escritos por colegas de Centro América. La decisión de iniciarnos con esta región en particular vino dada por el auspicio recibido a esos fines del Centro para el Bienestar de la Niñez adscrito a la Universidad de George Mason, cuya meta va dirigida a promover espacios de crecimiento profesional para los trabajadores y trabajadoras sociales centroamericanos. En los próximos números, sin embargo, la Revista Análisis abrirá sus páginas no solo a los colegas de Puerto Rico sino también a aquellos y aquellas provenientes de los países de habla española. Pretendemos así ser fieles exponentes de los valores de la profesión de trabajo social a los que hemos hecho referencia y que pueden resumirse en un compromiso profundo con la justicia social y económica y con el desarrollo de una práctica profesional efectiva, basada en firmes y claras conceptualizaciones de la realidad social y del comportamiento humano. 